\title{
Students' Use of Languaging in Rewriting Events from The Things They Carried
}

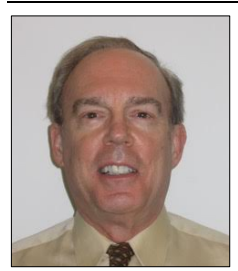

\author{
Richard Beach
}

University of Minnesota, USA

\begin{abstract}
This article describes high school students' responses to events in the novel, The Things They Carried, leading to their collaborative rewriting to create their own narrative versions of these events. It draws on "enactivist" theory of languaging, an approach to language that focuses on its use as social actions to enact and build relationships with others (Cowley, 2011; Linell, 2009). The focus is on "in-between" meanings constituted by "shared intentionality" (Di Paolo \& De Jaegher, 2012) in readers' transactions with authors' portrayals of events in texts as well as in responding to uses of languaging in characters' interactions. Analysis of four students' rewriting events from the novel indicated that they drew on their responses to the novel to portray tensions in their characters' interactions as well as their own experiences of coping with these tensions. Students also benefitted from collaboratively creating their narratives through sharing their different perspectives on events in the texts, suggesting the value of using collaborative rewriting activities to enhance students' literary responses and awareness of how languaging functions to enact relationships.
\end{abstract}

Key words: reader response, narratives, events, storywriting, languaging, sense-making, interactions, collaboration, composition.

Richard Beach is Professor Emeritus of Literacy Education at the University of Minnesota. His research focuses on literary response, digital writing, and uses of language. He is co-author of Teaching Climate Change to Adolescents: Reading, Writing, and Making a Difference (http://climatechangeela.pbworks.com); Teaching Literature to Adolescents, $3^{\text {rd }}$ ed. (http://teachingliterature.pbworks.com); Understanding and Creating Digital Texts: An ActivityBased Approach (http://digitalwriting.pbworks.com); Literacy Tools in the Classroom: Teaching Through Critical Inquiry, Grades 5-12 (http://literacytooluses.pbworks.com), and High School Students' Competing Social Worlds: Negotiating Identities and Allegiances through Responding to Multicultural Literature. He served as organizing editor for the annual Annotated Bibliography of Research for Research in the Teaching of English from 2003 to 2012 , former President of the National Conference on Research in Language, and former President of the Literacy Research Association.

$\cos \cos 80$ 


\section{Students' Use of Languaging in Rewriting Events from The Things They Carried}

Richard Beach

\section{Introduction}

In responding to literature, students often engage in literary response writing activities based on the instruction to interpret the meaning of a text according to "what the text says explicitly." Such guidance may lead to students adopting of a "strong text" model (Brandt, 1990, p. 35). However, adopting this "strong text" model, which comes with an implicit assumption that the meaning of a text resides "in" the text, positions students to adopt a relatively passive stance to extract this predetermined meaning. Fostering students' construction of their own meanings through a dialogic, sense-making transaction between themselves and the text (Rosenblatt, 1978; Masny, 2014) avoids their adopting a passive stance in responding to a text.

This reader-text transaction is mediated through language. To understand how readers use language in this transaction for responding to texts and rewriting events from a text, in this article, I draw on enactivisit theories of "languaging" (Cowley, 2011; Linell, 2009) that go beyond structuralist theories of language as a code system to focus on how language is used to create relationships through collaborative interactions with others (Agha, 2007; Cappuccio \& Froese, 2016; Garcia \& Wei, 2014; Linell, 2009; Madsen, 2016). I illustrated the application of a "languaging" perspective to analyze examples of four high school students' rewriting of events in different stories from The Things They Carried (O'Brien, 1990). A "languaging" perspective provides insights into how the students employed language in their use of dialogue and descriptions to portray characters' actions as reflecting certain practices and ideological stances associated with larger thematic meanings addressed in the novel. In applying this languaging perspective to analyze the students' rewriting events from The Things They Carried, I was interested in how the students would dramatize the characters' interactions using language as social actions to portray dialogic tensions in the characters' interactions.

\section{The Teachers' Response and Rewriting Activities}

In my work with teachers in a suburban Midwestern high school, I learned that one of the teachers, Ms. Bianchi, who was teaching The Things They Carried (O'Brien, 1990) in an $11^{\text {th }}$ grade American Literature AP class, had employed a series of activities for rewriting events in the novel.

Prior to this rewriting assignment, Ms. Bianchi asked all of her students to read the story "On the Rainy River" from the novel. In that story, the main character of the novel, Tim, having been drafted to serve in the Vietnam War, must decide on whether to avoid going to Vietnam by going Canada as a sign of support for the anti-war movement or whether to go and serve in Vietnam, something he knows would please his patriotic family and friends in his small Minnesota town.

In the story, Tim goes to a lodge on the Rainy River on the Minnesota/Canadian border to contemplate whether or not he should risk crossing into Canada. He establishes a relationship with the lodge owner, Elroy, and the final day of his stay at the lodge, Elroy takes Tim fishing in a boat out on the river, which Tim perceives as a test to determine if he would swim from the boat to escape to Canada:

I think he meant to bring me up against the realities, to guide me across the river and to take me to the edge and to stand a kind of vigil as I chose a life for myself.... My whole life seemed to spill out into the river, swirling away from me, everything I had ever been or ever wanted to be. I couldn't get my breath; I couldn't stay afloat; I couldn't tell which way to swim (O'Brien, 1990, pp. 53-54).

He then imagines his family members, school friends, teachers, and townspeople, as well as antiwar protesters standing on the shoreline-

Dialogic Pedagogy: An International Online Journal | http://dpj.pitt.edu

DOI: 10.5195/dpj.2017.181 | Vol. 5 (2017) 


\section{Students' Use of Languaging in Rewriting Events from The Things They Carried}

Richard Beach

a million ferocious citizens waving flags of all shapes and colors- people in hard hats, people in headbands - they were all whooping and chanting and urging me toward one shore or the other ( $p$. 56).... "Traitor!" they yelled. "Turncoat! Pussy!" I felt myself blush. I couldn't tolerate it. I couldn't endure the mockery, or the disgrace, or the patriotic ridicule (p. 57).

Tim is also aware of the owner, sitting in the boat watching him as he contemplates making his decision as the

true audience. He was a witness, like God, or like the gods, who look on in absolute silence as we live our lives, as we make our choices or fail to make them. "Ain't biting," he said. Then after a time the old man pulled in his line and turned the boat back toward Minnesota (p. 57).

Ms. Bianchi asked the students to write their responses to the story by examining how "location can influence one's views about the world and one's place in it. Because our main character is so deliberate in his wanting to make a decision, it becomes clear to see how 'space' influences him."

In reflecting on the purpose for her assignment, Ms. Bianchi noted that she wanted her students to understand

how Tim's beliefs are challenged or shaped. We can see that old man presents a calm and judgment-free zone in the canoe. Tim's values surface.

Part II of the activity asks students to look at themselves. It is harder for them to see where they might be influenced. I use the space of church to show how they may be influenced. Some behave differently there than at school. I ask them to look at different places they go-cabins, church/temple/mosque, school, shopping malls, work, home, etc., before they begin answering the questions (Ms. Bianchi's written reflection on this assignment).

Her assignment served to encourage students to examine how characters' beliefs and values influence their actions within certain situations or spaces. She was also having students consider how they draw on their own experiences within these situations or spaces to apply to their responses to literature, i.e., she conceptualized this as the use of transfer that would be useful for engaging students in rewriting activities.

She then had the students select a specific event from a story in the novel to collaboratively work in pairs to re-write that event based on adopting one of the character's perspectives to create their own version of the event (Beach, 2017). This engaged the students in rewriting activities that involve students in employing their own languaging to portray interactions between characters (Fjällström \& Kokkola, 2015; Yang, 2016).

Ms. Bianchi then gave the students this assignment for rewriting events from a story of their choice from the novel:

Please look at your short story through another character in the story's perspective. Perhaps it is the father, or girlfriend, or another character that is mentioned who may or may not have as much insight as you do in the story. 


\section{Students' Use of Languaging in Rewriting Events from The Things They Carried}

Richard Beach

Retell one of/or the major event suggested from the short story in that character's perspective. You need to consider how your NEW character is shaped by what has occurred. Please consider these areas where it is appropriate:

- $\quad$ their level of direct versus indirect involvement in an event as participant or bystander

- $\quad$ the degree to which there were positive or negative consequences for them due to their participation in an event

- $\quad$ their emotional/attitudinal stance on an event

- $\quad$ their relationship with or empathy for participants in an event

You will create a shared document with one other person who also has your story. You will retell the event or story from the other character's point of view (Ms. Bianchi's assignment).

To foster reflection on their composing processes, Ms. Bianchi and I developed the following questions to have students write about their rewriting experience:

- $\quad$ How would you describe A's perspective about their past relationship with B and B's perspective on A? How did you employ certain points of view to portray these perspectives?

- What traits, needs, perspectives, emotions, and agendas did you draw on from the text to create your characters' interactions?

- As the event unfolds, what alternative things could have happened at this point and why? Did those things happen or not happen?

- What specific experiences and/or relationships in your own life, if any, did you draw on to portray their relationship through your use of dialogue?

- What overall meaning(s) did you want your readers to draw from reading your version of this event?

Ms. Bianchi noted that her objective for this rewriting assignment was to foster students' empathy related to understanding "the actions of the characters and be able to provide some sort of explanation or 'other side' to work with. Robust discussion around the actions/empathy was the motivation for having them work in small groups." She encouraged students to draw on their own experiences with conflicts in their own relationships to portray conflicts between their characters, encouraging them to use both dialogue and their own perceptions in writing their narratives.

\section{Using Languaging in Responding to and Rewriting Events from Literary Texts}

A languaging perspective provides useful insights to examine the students responding to and rewriting of characters' actions in events from the novel. Focusing on languaging means focusing on how language is used as social action to interact with others to create or maintain certain kinds of relationships, for example, a "teacher-student" relationship acquired through "doing things together" in joint activities (Raimondi, 2014). Responding to and portraying how characters use languaging assumes that language is "inseparable from and constitutive of the actions and reactions of people in response to each other. It is through languaging that people act on each other, performative and commissive acts through which people establish their and others' personhood" (Bloome \& Beauchemin, 2016, p. 152).

When people use language to engage in specific actions to accomplish certain goals in interacting with another person, we describe it as "languaging". The other person perceives these actions 


\section{Students' Use of Languaging in Rewriting Events from The Things They Carried}

Richard Beach

as having certain intended uptakes or effects, for example, the statement, "I didn't find the mail on the kitchen table" may be perceived as an action of describing, judging, or complaining.

N. J. Enfield (2013) posits that audiences infer these actions' uptakes or effects as enacting certain social practices as conventionalized tools for interacting with others. Moreover, the meanings of these social practices are identifiable across different contexts. An audience may infer that "I didn't find the mail on the kitchen table" as making a complaint based on previous interactions between the speaker and audience-given that in their previous interactions, the speaker consistently engaged in the practice of complaining about the audience's behavior.

Because both speaker and audience are inferring the meaning of actions as implying certain practices, the meaning of these actions resides in the "in-between" space constituted by participants' constructing a "shared intentionality" through "participatory sense-making" (Di Paolo \& De Jaegher, 2012, p. 2). This assumes that "social understanding is as much an interactional as an individual affair" (Fuchs \& De Jaegher, 2009, p. 4), requiring some joint, shared agreement regarding the "in-between" meaning of an interaction. If a speaker is employing romantic "sweet talk" to impress their hearer, any positive meaning or uptake associated with that "sweet talk" depends on both the speaker and hearer reciprocally sharing the same "in-between" meanings-that the "sweet talk" is being used to impress the hearer and the hearer responds accordingly.

Breakdowns in interactions occur when participants do not share the same "in-between" meanings resulting in interactions with another person being challenged, supported, extended, or revised depending on the interaction (Cuffari et al., 2015). If the hearer perceives the "sweet talk" as inauthenticas actions based on the practice of deceiving the hearer - the hearer may then challenge the speaker's motives.

It is also the case that speakers' and hearers' identities are constituted by and through languaging - that "identities are not fixed and stable attributes of individuals, but are produced through language (and other) activities.... Language and identity, therefore, are the products rather than the precursors of our language activities" (Pennycook, 2011 p. 125).

In responding to Tim and Elroy's use of languaging in "On the Rainy River," the students were inferring these "in-between" meanings. These "in-between" meanings were becoming a part of Tim's identity in his contentious relationships to the imagined audiences on the shoreline, as well as to Elroy's identity constituted through his laconic interactions with Tim.

In rewriting material from the novel, students were drawing on their responses while actively creating or enacting their own versions of those events. As Popova (2014) notes, in responding to events in texts

we enact them; we invest them with a speaker that we treat as a conversational participant; we become willing partakers in their worlds, but they also become part of ours. Narratives constitute both interventions in our sense-making powers as readers, and are, reciprocally, the dynamic constructs of the intervention itself (p. 8).

This enactment of the reader with a character involves a "relationship between the actual present reading subject ("I"), and the subject's position as "in-between" in the interpretation of the text ("Me" + "text")" (Lysaker, 2014, p. 587). 


\section{Students' Use of Languaging in Rewriting Events from The Things They Carried}

Richard Beach

To rewrite events from the text, the students drew on their responses to O'Brien's original language and created their own version of the events to convey their intended meanings. Rather than frame this reader-text transaction in terms of a cognitivist "theory-of-mind" perspective based on mentalist notions of an autonomous reader intuiting characters' minds (Zunshine, 2006), a languaging perspective focuses on readers' enacting a "shared intentionality" (Tomasello, 2014) constituted through and by their "in-between" interactions with the text (Popova, 2014; 2015). While a "theory-of-mind" perspective assumes that readers can infer writers' or characters' autonomous, private mental states, a languaging perspective frames responding as an unfolding, intersubjective process of collaborative sense-making between readers and narrators or characters. In contrast with a mentalist "theory-of-mind" perspective, this focus on readers' sense-making as enactive intersubjectivity assumes that

1. Social understanding is as much an interactional as an individual affair.

2. Intersubjectivity relies heavily on embodiment in a rich sense of the word, i.e. on dynamical and embedded whole-body actions.

3. Intentions are not opaque and hidden but are expressed in action and can be perceptible to others.

4. Intentions are not pregiven and static but can be generated and transformed in the process of interacting. (Fuchs \& De Jaegher, 2009, p. 469)

I was therefore interested in how the students drew on their intersubjective sense-making to rewrite events from the novel to portray tensions in their characters' relationships, tensions associated with the practices of 'opening up' or 'closing down,' being responsive or reticent, making signs of approach or withdrawal" (Jensen, 2014, p. 11). To portray these practices, students were drawing on their knowledge of causal connections between previous, current, and subsequent events from the novel as well as their experiences of coping with tensions and conflicts in their own personal relationships.

\section{Rewriting the "Love" Story}

Two students, Samantha and Elizabeth (all student names are pseudonyms), collaboratively created a narrative version of a college reunion event in the "Love" story from The Things They Carried. In that story, Lieutenant Jimmy Cross, a soldier who served with Tim in the Vietnam War, is now visiting with Tim after the war. He describes his experiences of attending a college reunion to reunite with Martha, his former college girlfriend, who had continued to write him letters during the war. Jimmy is still in love with Martha while she is uneasy about being with him, given her previous encounters with him when they were dating in college.

In the novel, when he is in Vietnam, Jimmy recalls his previous college relationship with Martha, his perceptions of her loneliness, and the fact that she did not reciprocate his love:

"He wanted to know her. Intimate secrets: Why poetry? Why so sad? Why that grayness in her eyes? Why so alone? Not lonely, just alone_ riding her bike across campus or sitting off by herself in the cafeteria - even dancing, she danced alone - and it was the aloneness that filled him with love. He remembered telling her that one evening. How she nodded and looked away. And how, later, when he kissed her, she received the kiss without returning it, her eyes wide open, not afraid, not a virgin's eyes, just flat and uninvolved" (O'Brien, 1990, p. 11).

When they reunite at their college reunion, Jimmy learned that she was

"a Lutheran missionary now. A trained nurse, although nursing wasn't the point, and she had done service in Ethiopia and Guatemala and Mexico. She had never married, she said, and probably

Dialogic Pedagogy: An International Online Journal | http://dpj.pitt.edu

DOI: 10.5195/dpj.2017.181 | Vol. 5 (2017) 


\section{Students' Use of Languaging in Rewriting Events from The Things They Carried}

Richard Beach

never would. She didn't know why. But as she said this, her eyes seemed to slide sideways, and it occurred to him that there were things about her he would never know. Her eyes were gray and neutral. Later, when he took her hand, there was no pressure in return, and later still, when he told her he still loved her, she kept walking and didn't answer and then after several minutes looked at her wristwatch and said it was getting late" (O'Brien, 1990, p. 27).

In these descriptions of their interactions, O'Brien highlights Martha's embodied responses to Jimmy as implying her not reciprocating his love for her.

In their own story, "Martha's Perspective: Love," the students employ Martha's first-person pointof-view to portray her growing anxiety about re-uniting with "Jim" (used by the students in lieu of "Jimmy") after his experience of being in Vietnam:

Walking into my college reunion, my heart was racing and I was filled with numerous emotions: worried, excited, hopeful, and confused. The reason behind this was because the man I had history with would be there. I didn't know what would happen between us throughout the night, or if anything even would happen. The moment our eyes connected from across the room, I was taken back. I noticed from the corner of my eye him walking towards me.

"Martha, nice to see you again! It has been ages, you look as beautiful as ever," Jim exclaimed.

"Hello Jim! Yes, it has been awhile, hasn't it?" I could tell right at the beginning of this conversation that he was still in love with me since college. He must have never stopped. The look in his eyes and the way his voice was shaking gave this away. It was almost like no time had passed. I didn't know if I could reciprocate this feeling, but I decided to spend the evening with him. (Samantha and Elizabeth's narrative writing)

In portraying Martha's not knowing "if I could reciprocate" Jim's love as a larger practice reflected in her actions, the students are dramatizing tensions between Jim and Martha as possibly having significant implications for what would happen as their interaction unfolds. Dramatizing the significance of key events in their stories involves what Bakhtin (2011) describes as portraying "eventness" through implying that certain significant potential consequences may occur depending on what happens in an event (Köppe, 2014). Dramatizing the unpredictability of unfolding "events-in-the-making" (Roth, 2014) "restores the possibility of possibility" (Morson, 2010, p. 118), in ways that "redirects our attention to the present moment, its multiple conflicts, its multiple possibilities" (Welch, 1998, p. 377), thereby heightening the suspense associated with the narrative significance of an event. By having Martha state that she “'didn't know if I could reciprocate," the students are dramatizing the "eventness" of her encounter with Jim through portraying the unpredictability of what may or could happen in their interaction.

In her reflection, Elizabeth noted that Martha is "nervous and didn't know what to expect. I also wanted the readers to think that there could be a possibility of them ending up together in the end...but Martha doesn't necessarily love him back the same way. She is almost incapable of love you could say; she is confused and just doesn't share the same feelings."

The students drew on information about Jimmy and Martha from the novel to portray tensions in their characters' interactions. In the novel, Jimmy is portrayed as blaming himself over the loss of a soldier in his platoon, as well as assuming that Martha loves him based on the fact that the letters he was receiving from Martha during the war were signed, "Love, Martha." Martha is portrayed as having had a previous negative interaction with Jim on a movie date as an allusion to previous sexual abuse shaping her current stances towards Jim. 


\section{Students' Use of Languaging in Rewriting Events from The Things They Carried}

Richard Beach

In drawing on their responses to these previous events in the novel, the students are using these past events to portray Jim and Martha's current perceptions of each other. In Bakhtin's words, "relationships of family, or life-story and biography, or social status and social class are the stable alldetermining basis for all plot connections; contingency has no place here" (Bakhtin, 1984, p. 104). In her reflection on their portrayal of this interaction, Samantha noted:

Their relationship was left with things unsaid and unresolved. Jim made her feel a whole range of emotions that made her uncertain of her true feelings... They never had an official relationship. Jim had been in love with her since college but Martha never indicated her love for Jim (Samantha's written reflection).

The students then portray Jim and Martha walking back to their dorm when Martha envisions the possibility that Jim might propose marriage, a possibility enhancing the "eventness" of their interaction given Martha's resistance to any thought of marriage:

The night started out with a banquet, we had a nice meal together. Later, we danced together for what seemed like hours, but it was probably only a few minutes. Lastly, we went for a walk. He asked me about my life, I explained to him how I am a Lutheran missionary, and how I trained for nursing but that was beside the point. I told him I wasn't married but then immediately looked away in discomfort just in case he got the idea that I was hoping for a future with him. I didn't know exactly what I wanted in life, but for some reason, I cannot explain, marriage was not one of my plans (Samantha and Elizabeth's narrative writing).

Samantha noted that in portraying this event, they "wanted to make it clear that Martha didn't want to give Jim the wrong impression or lead him on.... We showed the feeling of discomfort and unease when Martha looked away after saying she wasn't married." Elizabeth described different possibilities for Martha's potential actions, that

she could have hinted that she was looking for something more serious. She could have gotten him back because it is obvious he still loves her. She could have made a move and showed she wanted something more like marriage. The reason it did not happen was because she didn't like him in that way and didn't want to steer him in the wrong direction. She wanted to keep things friendly and not do anything she would later on regret (Elizabeth's written reflection).

In their reflections on this interaction, the students are noting that they wanted to portray Martha as being reluctant to openly express her resistance to Jim's agenda. They therefore employ actions reflecting the larger practice of what Samantha identifies as "Martha not wanting to lead him on." Elizabeth noted that they portrayed Martha as not making a move because they wanted to portray Martha's inner thoughts about her use of language in responding to Jim's expression of love. The students' use of metaphors of "leading," "moving," and "steering" suggest how they used the characters' languaging as social actions to portray the practices of Martha's physical and psychological positioning of Jim to avoid his advances.

In Samantha and Elizabeth's story ending, Jim and Martha are standing outside a college dorm:

At this point in the night he grasped my hand, waiting for me to squeeze it back. I did not want to give him any ideas so my hand just sat there limp.

"Martha, I love you!" He confessed to me. 


\section{Students' Use of Languaging in Rewriting Events from The Things They Carried}

Richard Beach

"Um, it's getting late, I need to get home." I nervously responded, while looking at the time on my wrist.

"Wait, I regretted letting you go the last date we went on. I wanted to tie you to my bed and never let you go."

I turned away, very uncomfortable by his statement. I never will understand why men act this way towards women. For some reason a part of me feels bad for responding the way that I did (Samantha and Elizabeth's narrative writing).

As in the previous interactions, the students portray Jim and Martha as having conflicting expectations for this final interaction, leading to a breakdown. They have Jim engaging in the practice of proposing by expressing his love for her while also describing his recollection that "I wanted to tie you to my bed and never let you go," resulting in negative uptake from Martha who is "very uncomfortable, by his statement."

The students also employ descriptions of emotions to dramatize the "eventness" of this breakdown in any mutually shared understanding. Samantha notes how "Jim was desperate for Martha's love. He didn't know how to express it and said too much; [Martha] was also very uncomfortable and confused by Jim's efforts." Elizabeth notes that

Martha just feels disgusted as would many girls. At the very end when Martha felt bad for responding the way that she did it shows that girls are submissive in society and almost let men control their feelings. She had no reason to feel bad for turning away when he made her feel uncomfortable but thinking about what happened later on she thought she did the wrong thing (Elizabeth's written reflection).

Elizabeth is referring to how Martha recognizes Jim's mode of interacting with her as an embodied manifestation of his patriarchic stance, a reflection of how certain beliefs are shaping the characters' interactions. At the same time, Elizabeth alludes to Martha's dialogic tension related to the possibility that she might have helped Jim, a reflection that their story ending was ambiguous associated with defying use of any easy narrative closure.

\section{Rewriting the "Ambush" Story}

Two other students, Sharon and Michelle, created their story, "It Didn't Kill Us, But it Changed Us," based on the story, "Ambush" in the novel. In the "Ambush" story, Tim, while on watch for his platoon, kills a Vietnamese soldier. In the original story, Tim expresses his guilt about doing so to Kiowa, the first-person narrator of the story (both in the original and in the rewrite by the students).

In the novel, Kiowa attempts to help Tim cope with his guilt in killing this soldier, by formulating a justification for killing the soldier given that

"It's a war. The guy wasn't Heidi- he had a weapon, right? It's a tough thing, for sure, but you got to cut out that staring" (p. 120)..."The guy was dead the second he stepped on the trail. Understand me? We all had him zeroed. A good kill- weapon, ammunition, everything. So listen, you best pull your shit together. Can't just sit here all day" (O’Brien, 1990, pp. 120; 123).

The students employ languaging to portray Kiowa's and Tim's interactions related to Kiowa's justification for killing and Tim's sense of guilt about the killing as reflecting larger thematic meanings 


\section{Students' Use of Languaging in Rewriting Events from The Things They Carried}

Richard Beach

about the influence of war on humans. Sharon describes her sense of the "eventness" of this event given that it

was a decisive moment in the relationship between Kiowa and Tim. Kiowa's concern for Tim shows that the two are friends as well as soldiers. They look out for each other and care about how the war affects one another. Kiowa's realization hints at the negative side of war. The passing of soldiers leaves families and friends behind to grieve without saying goodbye. Tim recalls that the soldier was "not a Communist. He was a citizen and a soldier [so that] he didn't belong in a war." We wanted to continue this story to show how that realization spread from one soldier to another. Although they are fighting on opposite sides, they are still the same (Sharon's written reflection).

Michelle noted that:

It was very significant for Kiowa and Tim in different ways. For Tim it was traumatizing because he had killed a man. For Kiowa it began as a traumatizing experience because he was worried about his friend, but eventually he was able to turn that worry into a respect for his friend, which shows a significant growth in his character through this event (Michelle's written reflection).

In their narrative, the students portray how Kiowa's own experience with war is shaping his psychological orientation in which he imagines being in a battle. In the first section of the students' narrative, Kiowa has been on patrol and then goes to wake up Tim:

"Tim, hey Tim, wake up!" I said while aggressively shaking my sleeping counterpart. I was exhausted from my watch and was focused on going to sleep.

"Okay, okay, calm down I'm waking up." Tim groggily responded. "Anything happen during your watch?"

"No, nothing worth repeating. Haven't seen anything along the trail for the past two hours. It's quite warm and hard to see though, just so you know."

"Alright, l'll take over. You can sleep now." As I laid down on the rough ground in the hot tent, my mind would not stop wandering. I began to think about the empty trail. After staring at the same dense brush for two hours, I had begun to imagine things, my mind began to play tricks on me. I would think someone would come along and then I would pick up the grenade and look back and realize it was just a bush. This was good practice for if a soldier really did come along, hopefully my reflexes would beat theirs and we wouldn't be spotted. (Sharon and Michelle's narrative writing)

In reflecting on their portrayals of Kiowa's experience of exhaustion, fear, and anxiety, Sharon notes that his experience of war "causes his mind to imagine threats that are not actually there. He is afraid of something happening so he imagines that it happens."

The students then portray Kiowa dreaming about going to his grandmother's house and embracing her. They portray their interaction as constituted by emotions of love and comfort distinct from his current emotions of exhaustion, fear, and anxiety in the war:

I saw that smile from the tiny little woman for the first time in months and emotion overflowed in my chest and eyes. I felt joy rush into me as I came face to face with my loving, nurturing grandmother. All the fear and worry I had felt over the past months instantly left me. I hugged my grandmother, feeling contentment, comfort, and safety, something that now felt foreign to me, but relief 


\section{Students' Use of Languaging in Rewriting Events from The Things They Carried}

Richard Beach

nonetheless. Suddenly I heard a popping noise that jolted me out of my slumber (Sharon and Michelle's narrative writing).

Sharon described how their descriptions of Kiowa's emotions constituting his interactions with his grandmother served to evoke their audience's experiences with similar emotions of love and nurturance in their own relationships:

We used words such as "loving" and "nurturing" to contrast the horror that Kiowa is about to experience. We also tried to use descriptions such as "emotion overflowed in my chest and eyes" in a way that readers could relate to. Many people have experienced an overwhelming amount of happiness that they start to cry; we hope that when readers read that description, they can relate to that feeling...one minute Kiowa feels relief with his grandmother, the next he is back in the war surrounded by his fears (Sharon's written reflection).

In the next section of the students' narrative, Kiowa discovers that Tim has killed a Vietcong soldier and realizes that

this would be hard on Tim, I could see it on his face. The same face l'd seen on Lieutenant Cross after he felt responsible for Ted Lavender's death. After that, Lieutenant Cross was never the same. I couldn't let that happen to Tim; he was a great soldier. Anyone on watch would have killed the man, otherwise we would have all been dead.... It was a horrific site and Tim knew this. I could practically read his thoughts. He knew he had killed a man and was thinking of the life he took away. I would have done it too, and Tim needed to understand that. He needed to remember the people he loved and the people who loved him in order to get out of his deep pit of despair (Sharon and Michelle's narrative writing).

In portraying Kiowa's first-person point-of-view perspective on the war and his need to help Tim cope with his guilt, the students are inviting readers to consider how this perspective will shape his interactions with Tim given that "there is always interplay between the past, the here and now, and the possible and imagined" (Bakhtin, 1981, p. 251, italics added). They portray Kiowa as recognizing Tim's struggle between his actions of killing and his past identity as resisting going to Vietnam as part of the anti-war movement. Their portrayal of Tim's struggle reflects the fact that his "ideological development is an intense struggle within us among various verbal and ideological points of view, approaches, directions, and values" (Bakhtin, 1981, p. 346, italics added).

Michelle noted how they wanted to portray

Kiowa's helplessness and his worry for Tim and it also shows how much emotional distress Tim is in. We also used the description of Tim's eyes and the comparison to Lieutenant Cross to show Tim's emotions. We showed Kiowa's worry turn into fear when he snapped and got slightly angry. That shows that he was losing hope in Tim's recovering because he became impatient and angry (Michelle's written reflection).

Through portraying Kiowa's conflicted perspectives on how the war is shaping Tim and himself, the students are using languaging to "double-voice" (Bakhtin, 1981) discourses of patriarchy, power, stoicism, and patriotism operating in the military system. Sharon indicated that they contrasted Kiowa's adoption of the stance of stoicism with the statement that "anyone on watch would have killed the man"” and Tim's reaction of shock that is in "contrast the typical image of a soldier." She also notes that they referenced "the death of Ted Lavender [that] affected Lieutenant Cross more than the other soldiers 


\section{Students' Use of Languaging in Rewriting Events from The Things They Carried}

Richard Beach

because he felt it had been his fault...This is where we drew on the Kiowa's caring nature towards both lieutenant and Tim."

In Sharon and Michelle's next section of their narrative, they introduce another soldier, Azar, who praises Tim for killing Vietcong soldier, much to the Kiowa's irritation:

"Man, you killed that kill!" Azar said. "Come on, get it? You killed it and you actually killed him," he continued.

"Shut up," I said.

"Aw, come on it's funny!" Azar said.

"Go away," I demanded.

Azar, still laughing to himself, walked up the trail toward the village, disappearing behind the trees.

"Just ignore him, he's not worth listening to," I said kneeling towards Tim. "Really you should just try

and forget about this, it's what anyone would've done" (Sharon and Michelle's narrative writing).

Portraying the differences in Azar's and Tim's perceptions of the event reflects how, as Sharon notes, "Azar uses humor as a defense mechanism" constituting a rationalization for killing in war, while Kiowa

tries to rationalize the situation in order to justify Tim's actions. He regrets the loss of this man's life; however he tries to explain to Tim that it was necessary for the survival of their rank. Tim, on the other hand, forgets the purpose of the war entirely. He succumbs to the guilt and shock he feels from killing this man, unable to escape his shock as Kiowa tries to reassure him (Sharon's written reflection).

Michelle noted how they were aware of their readers' perceptions of Azar:

Some could think of him as very rude and insensitive, while others could believe that his way of coping and trying to make people feel better is through humor. We were trying to make readers see that Azar coped with tragedies through humor (Michelle's written reflection).

The students use Azar's languaging as double-voicing ways of being and becoming (Bakhtin, 1981) through use of ironic humor for coping with the effects of war. Having Azar parody or double voice Kiowa's admonition serves to critique Kiowa's languaging actions constituting use of his practice of impersonal dismissal of Tim's guilt. The students are therefore portraying Azar as adopting the role of what Nodeh (2013) describes as the "Bakhtinian fool [who] is a comic character who is extremely mocked by the objective narrator but, as a matter of fact, is used as a mask for the author to criticize society" ( $p$. 404). They are also portraying dialogic tensions associated with Kiowa's admonishing Tim to "just try and forget about this, it's what anyone would've done," as opposed to his empathizing with Tim's guilt. shock:

In the next section, the students portray Kiowa's further attempts to help Tim break out of his

"Look at him. He was bound to be killed anyway. He's not a soldier, he looks like another civilian." I said in a desperate attempt to make him snap out of his shock. No matter what comforting words I attempted to give, his shock didn't waver. 


\section{Students' Use of Languaging in Rewriting Events from The Things They Carried}

Richard Beach

"Snap out of it! He's dead, staring at his body isn't going to change that. Come on we got a lot of work to do today," I insisted (Sharon and Michelle's narrative writing).

Sharon notes that in they wanted to portray Kiowa's emotions of "frustration, regret, and realization. Kiowa is originally frustrated when he cannot get Tim to snap out of his daze." She also suggests "the potential that Kiowa could have gotten extremely upset, he could have lost all hope, or even Tim could have had a meltdown."

In the final section of Sharon and Michelle's narrative, in removing items from the dead soldier's body, Kiowa finds:

a picture of a beautiful young woman. The image of her beautiful, young face twisted into sorrowful despair upon hearing the news of her loved one's death slowly crept into my mind. I instantly started to regret my rash outburst of frustration I had unleashed on Tim. It became clear to me that the war had not affected Tim enough to turn him inhumane. I picked up a nearby poncho to place over the young soldier, symbolically placing him to rest as if we had just held a funeral ceremony for him. I prayed for only one thing: to be able to be considered as righteous and thoughtful of a human being as my wonderful friend, Tim O'Brien (Sharon and Michelle's narrative writing).

Through describing Kiowa's regrets about how his earlier use of dismissive language was counter-productive, the students are portraying Kiowa's awareness of his own use of languaging in impacting his relationship with Tim. As Sharon notes:

Kiowa realizes that the soldier, much like himself, has a family at his home that miss him and that he had a life separate from the one he had been living in the war. This causes Kiowa to also realize that this is what caused Tim's shock and Kiowa regrets bursting out at Tim (Sharon's written reflection).

When asked about the overall meaning(s) the students wanted to convey in their narrative, Sharon noted that they wanted their readers to recognize tensions related to societal expectations about soldiers in war,

that soldiers are people to be respected because they do the most difficult job in the world. They are brave, tough, and selfless. We wanted to show that, although all this may be true, they are also human beings, not superheroes from comic books. Soldiers, just like everyone else, are affected by what they witness, can be haunted from living their nightmares, and need to be treated with compassion by those around them (Sharon's written reflection).

Michelle noted that they wanted to portray the differences in the effects of war on the characters:

that Azar struggled with how to handle difficult situations, Kiowa constantly longed to be home, Lieutenant Cross buried himself inside, and Tim struggled to cope with killing a man. Not all of these effects were bad things, often times they showed that soldiers are human too (Michelle's written reflection).

The students' reflections suggest that they were portraying the impact of war and the military on Kiowa, shifting between an impersonal "I-it" (Buber, 2004) relationship with Tim to adopting an "I-thou" caring relationship associated with Kiowa's willingness to take responsibility for helping Tim, responsibility as defined by Bakhtin as carrying "two intertwined meanings: being is a matter of responding to 
situational demands and possibilities, and the individual is responsible for the responses he or she makes" (Skaftun, 2011, p. 48).

\section{Applying Lived-World Experiences to Rewriting Events}

In creating their narratives, the students drew on their lived-world, personal experiences, reflecting Bakhtin's description that

behind the narrator's story we read a second story, the author's story; he [sic] is the one who tells us how the narrator tells stories, and also tells us about the narrator himself. We acutely sense two levels at each moment in the story; one, the level of the narrator, a belief system filled with his objects, meaning and emotional expressions; and the other, the level of the author, who speaks (albeit in a refracted way) by means of this story and through this story (Bakhtin, 1981, p. 314) (quoted in Nodeh, 2013, p. 2).

To portray the tensions between their characters, the students were drawing on their beliefs or discourses to "double-voice" (Bakhtin, 2011) those beliefs or discourses through use of languaging. They portrayed Martha's rejection of Jim's expression of love not as an outright, explicit rejection, but rather as a reflection of their own perceptions of sexist gendered discourses shaping relationships, as well as their sense of ambiguity about how to cope with power differentials in these relationships. Samantha described how she drew on experiences of adopting ambiguous stances in her own relationships to portray how Martha:

wanted to be treated with respect and Jim did not indicate that it was how he would treat her. With someone liking me more than I like them and vice versa, can be hard to deal with in both circumstances. In the situation with Jim loving more, I can understand how it hurts to put everything on the table and like a person so much but not have it be mutual (Samatha's written reflection).

Elizabeth reflected on how she drew on her own experiences of being positioned as a sex object to portray Jim's perceptions of Martha:

Sometimes when at a public place like the mall, men catcall or street harass women and they always ignore or just find a way to leave without submitting to them. This has happened to me as it has to almost every female. Like Martha when Jim says he wants to tie her to the bed all night, she feels uncomfortable and disgusted and wants to leave the situation just like women feel like when getting catcalled (Elizabeth's written reflection).

In describing how they drew on lived-world experiences for writing their story, Michelle and Sharon noted their portrayals of Kiowa's regret in initially failing "to explain and describe how Tim was feeling" over killing the Vietcong soldier were based on their own experiences of regret. Sharon cited her experience of regret with

situations in which I didn't look deep enough into and ended up regretting my ignorance. At times I have jumped to conclusions or irrationally released my frustration on the wrong person and in the end I regret not looking at the broader picture, instead of focusing on just my situation (Sharon's written reflection).

Michelle noted this sense of regret stems from not knowing how to effectively communicate support in 
trying to help my friends when they are in need...it can be hard to figure out the right thing to say and when you cannot help it can be frustrating which is what happened between Kiowa and Tim (Michelle's written reflection).

By drawing on their own experiences of dialogic tensions in relationships, the students recognized the need to capture the complexity of their characters' interactions associated with Martha's reticence in reuniting with Jim and Kiowa's difficulties in assisting Tim.

\section{The Benefits of Rewriting Events in Texts for Responding to Literature}

These four students' work suggests that there are a number of benefits in having students engage in rewriting stories to enhance their understanding of how languaging serves to construct characters' relationships in literature. In rewriting events from the texts, the students were going beyond simply responding to a text to employing languaging to portray actions constituting practices shaping characters' relationships. Adopting and creating Martha's and Kiowa's first-person perspectives required that the students draw on their interpretations of these characters' beliefs, history, and identities to portray how those beliefs, history, and identities shaped their characters' use of languaging constituting their 'inbetween" "shared intentionality" (Di Paolo \& De Jaegher, 2012, p 2) for portraying their relationships with Jim and Tim.

Students also benefitted from engaging in the rewriting through their use of their collaboration for sharing ideas and revising their texts, benefits consistent with research on the value of collaborative writing (Dobao, \& Blum, 2013; Fjällström \& Kokkola; Shehadeh, 2011; Wigglesworth \& Storch, 2012). Through their collaboration, the students engaged in "collective scaffolding" by drawing on each other's knowledge and perspectives in their interactions (Donato, 1994). As Michelle noted, "our story would have been much different if we hadn't worked together."

In their collaboration, students tested out alternative revisions to determine what options would best serve to convey their overall thematic meanings; for example, as Sharon describes, "we decided that having Kiowa get frustrated with Tim's lack of response was the most realistic and relatable. I believe that if we had written this story separately, the general purpose of the story would be lost."

This included collaboratively rehearsing oral interactions to create characters' dialogue by translating oral language into a written mode (Kravchenko, 2016), reflecting the students use of "participatory sense-making" (Di Paolo \& De Jaegher, 2012, p. 2). Elizabeth described talking "about different ideas and whatever sounded the best we typed up." As Samantha noted "Elizabeth and I were able to incorporate both of our styles of writing. We bounced ideas off of each other to make sure that we equally had a part and it flowed coherently."

The students' awareness that they employed different writing styles, resulting in the need, as Elizabeth noted, to make "sure it all flowed together nicely and made sense so it had the same writing style throughout," reflects an awareness that use of languaging itself mediated their collaboration. In a related study, analysis of four EFL Chinese college students collaborative rewriting of a story written in English found that the students employed languaging to mediate their own interactions (Yang, 2016). This use of languaging helped them cope with issues of translation and portrayal of characters' interactions so that "languaging served as a means and a platform for the participants to exchange their ideas and talk about the language they were learning" (p. 253). Such collaborative interaction may also benefit students engaged in argumentative writing through engaging in exploratory talk to grapple with communicative 
struggles to make explicit students' thinking about an issue or topic (Brown, 2016; Cervetti et al, 2014; Sherry, 2014).

\section{Fostering "Participatory Sense-making" in Classroom Spaces}

One advantage of Ms. Bianchi's rewriting assignment was that she did not limit the students to having to conform to generating a particular type of rewriting consistent with a predetermined outcome or having to employ a particular strategy in their rewriting. Aukerman (2013) contrasts the pedagogical approach of "comprehension as sense-making" in responding to texts as distinct from a "comprehensionas-outcome" pedagogy in which students need to conform to achieving certain predetermined outcomes or a "comprehension as procedures" pedagogy requiring students' demonstration of use of specific procedures. In contrast, the "comprehension as sense-making" approach reflected in Ms. Bianchi's assignment supports students' open-ended grappling with uncertainties in characters' relationships, leading to rewriting of events (Aukerman, 2013). The fact that the students were puzzled by Martha's ambiguous stance towards Jim as well as Kiowa's initial impersonal response to Tim's grief reflects their willingness to grapple with their own uncertainties about seemingly complex events, a reflection of "comprehension as sense-making."

One approach to encouraging students to acknowledge and share their own misunderstandings or uncertainties in discussions about characters' languaging is to encourage students to frame their responses as tentative hypotheses or speculations-as "I'm-not-so-sure-about-this" "passing theories" (Kent, 1993) as opposed to honoring definitive, authoritative statements. Voicing responses as tentative hypotheses or speculations serves to invite others to engage in "participatory sense-making" to collaboratively explore hypotheses or speculations (Cappuccio \& Froese, 2016; Kamberelis, McGinley, \& Welker, 2015). In an analysis of an adult book club's discussions, participants were more likely to extend discussion of a topic across a series of turns when that topic was initiated as a "passing theory" (Kent, 1993) that served to invite others to share their responses (Beach \& Yussen, 2013). Sensing that a member of the book club was grappling with a challenging issue or topic encouraged other members to collaboratively grapple with that issue or topic.

In rewriting events from texts, students may be concerned about the degree to which they can deviate from the original text in creating their own versions of events from the text. Addressing these concerns of verisimilitude can lead to discussions of the larger epistemological issue of whether it is possible to derive a definitive understanding of any lived-world or fictional event (Baxter, 2011). For example, in responding to The Things They Carried, students may discuss reasons for O'Brien's references to his own issues involved in creating fictional versions of events that may have had no basis in any factual reality (Calloway, 1995; Clarke, 2013). Throughout the book, O'Brien references the challenge of representing the reality of an event through fiction which is paradoxically employed to portray the reality of "what happened (in Vietnam) ... what might have happened, what could have happened, what should have happened, and maybe also what can be kept from happening or what can be made to happen" (Beidler, 1982, p. 87). As O'Brien noted, "You start sometimes with an incident that truly happened . . . and you carry it forward by inventing incidents that did not in fact occur but that nonetheless help to clarify and explain" (O'Brien, 1990, p. 158), competing perspectives that defy definitive understanding of an event.

\section{Conclusion}

In conclusion, the four students benefitted from rewriting events in texts using languaging to portray the "eventness" of characters' interactions by drawing on their own experiences and emotions in 


\section{Students' Use of Languaging in Rewriting Events from The Things They Carried}

Richard Beach

interacting with others. Collaboratively creating their own versions of events in texts, helped these students engage in a rich transaction with the text given that they needed to employ languaging to portray dialogic tensions and complexities constituting their characters' relationships, suggesting the value of teachers' employing rewriting activities as supporting dialogic pedagogy. Through collaboratively interacting to engage in rewriting, students were employing their own languaging to share and revise text as itself an important collaborative practice (Fjällström \& Kokkola, 2015; Yang, 2016). By drawing on and perceiving connections between their own interactions with others in relationships to create the characters' interactions, students were experiencing transfer between their literary responses and their lived-world experiences, ideally leading to enhanced awareness of how languaging shapes their own relationships with others.

\section{References}

Agha, A. (2007). Language and social relations: Studies in the social and cultural foundations of language. New York: Cambridge University Press.

Aukerman, M. (2013). Rereading comprehension pedagogies: Toward a dialogic teaching ethic that honors student sensemaking. Dialogic Pedagogy: An International Online Journal, 1. Retrieved from http://tinyw.in/6rog

Bakhtin, M. M. (1981). Discourse in the novel. In M. Holquist (Ed.), The dialogic imagination (pp. 259492). Austin: University of Texas Press.

Bakhtin, M. M. (1984). Problems of Dostoevsky's poetics (V. W. McGee, Trans.). Minneapolis: University of Minnesota Press.

Bakhtin, M. M. (1986). Speech genres and other late essays. (Eds., C. Emerson \& M. Holquist. Trans. V. W. McGee). Austin: University of Texas Press

Bakhtin, M. M. (2011). Toward a philosophy of the act. (Trans. V. Liapunov.) Austin: University of Texas Press

Baxter, L. (2010). Voicing relationships: A dialogic perspective. Los Angeles: Sage.

Beach, R. (2017). Making sense of events in literature through rewriting narrative events. English Journal, 106(5), 54-59.

Beach, R., \& Yussen, S. (2013). Practices of productive adult book clubs. Journal of Adolescent and Adult Literacy, 55(2), 121-131. Doi: 10.1002/JAAL.00015

Beidler, P. (1982). American literature and the experience of Vietnam. Athens: University of Georgia Press.

Bloome, D., \& Beauchemin, F. (2016). Languaging everyday life in classrooms. Literacy Research: Theory, Method, and Practice, 65, 152-165.

Brandt, D. (1990). Literacy as involvement: The acts of writers, readers and texts. Carbondale:Southern Illinois University Press.

Brown, A. C. (2016). Classroom community and discourse: How argumentation emerges during a Socratic Circle. Dialogic Pedagogy: An International Online Journal, 4, A81-A96.

Calloway, C. (1995). "How to tell a true war story": Metafiction in The Things They Carried. Critique, 36(4), 249-257.

Caracciolo, M. (2012). Fictional consciousness: A reader's manual. Style, 46(1), 42-65. 


\section{Students' Use of Languaging in Rewriting Events from The Things They Carried}

Richard Beach

Cappuccio, M., \& Froese, T. (Eds.). (2016). Enactive cognition at the edge of sense-making: Making sense of non-sense. New York: Palgrave Macmillan.

Cervetti, G., N., DiPardo, A., \& Staley, S. J. (2014). Entering the conversation: Exploratory talk in middle school science. The Elementary School Journal, 114(4), 547-572.

Clarke, M. T. (2013). "I feel close to myself": Solipsism and US imperialism in Tim O'Brien's The Things They Carried. College Literature, 40(2), 130-154.

Cowley, S. J. (Ed.). (2011). Distributed language. Philadelphia: John Benjamins Publishing.

Cuffari, E. C., Di Paolo, E., \& De Jaegher, H. (2015). From participatory sense-making to language: There and back again. Phenomenology Cognition Science, 14, 1089-1125.

Di Paolo, E., \& De Jaegher, H. (2012). The interactive brain hypothesis. Frontiers in Human Neuroscience, 6(163), 1-16.

Dobao, A. F., \& Blum, A. (2013). Collaborative writing in pairs and small groups: Learners' attitudes and perceptions. System, 41, 365-378.

Donato, R. (1994). Collective scaffolding in second language learning. In J. P. Lantolf \& G. Appel (Eds.), Vygotskian approaches to second language research (pp. 33-56). Norwood, NJ: Ablex.

Enfield, N. J. (2013). Relationship thinking: Agency, enchrony, and human sociality. New York: Oxford University Press.

Fjällström, E., \& Kokkola, L. (2015). Resisting focalisation, gaining empathy: Swedish teenagers read Irish fiction. Children's Literature in Education, 46, 394-409.

Fuchs, T. \& De Jaegher, H. (2009). Enactive intersubjectivity: Participatory sense-making and mutual incorporation. Phenomenology Cognitive Science, 8, 465-486.

Garcia, O., \& Wei, L. (2014). Translanguaging: Language, bilingualism and education. New York: Palgrave.

Herman, D. (2011). Storytelling and the science of mind. Cambridge, MA: MIT Press.

Jensen, T. W. (2014). Emotion in languaging: Languaging as affective, adaptive, and flexible behavior in social interaction. Frontiers in Psychology, 5, \#720. Retrieved from http://tinyw.in/YUzq

Kamberelis, G., McGinley, W., \& Welker, A. (2015). Literature discussions as mangles of practice. Dialogic Pedagogy: An International Online Journal, 3. Retrieved from http://dpj.pitt.edu

Kent, T. (1993). Paralogic rhetoric: A theory of communicative interaction. Lewisburg, PA: Bucknell University Press.

Köppe, T. (2014). Narrative events. Storyworlds, 6(1), 101-116.

Kravchenko, A. V. (2016). Language as human ecology: A new agenda for linguistic education. New Ideas in Psychology, 42, 14-20.

Linell, P. (2009). Rethinking language, mind, and world dialogically: Interactional and contextual theories of human sense-making. Charlotte: Information Age Publishing.

Lysaker, J. T. (2014). Reading as a language event of the self: In conversation with Bertau, Lipari, and Karsten. Theory \& Psychology, 24(4), 576-591.

Madsen, L. M., Karrebaek, M. S., \& Moller, J. S. (Eds.) (2016). Everyday languaging: Collaborative research on the language use of children and youth. Berlin: De Gruyter. 
Masny, D. (2014). What is reading? A cartography of reading. In D. Masny \& D. R. Cole (Eds.), Mapping multiple literacies: An introduction to Deleuzian literacy studies (pp. 69-90). New York: Continuum.

Morson, G. S. (2010). The chronotope of humanness: Bakhtin and Dostoevsky. In N. Bemong, P. Borghart, M. De Dobbeleer, K. Demoen, K. De Temmerman \& B. Keunen (Eds.), Bakhtin's theory of the literary chronotope: Reflections, applications, perspectives (pp. 93-110). Gent: Belgium: Academic Press.

Nodeh, S. (2013). Dialogic narrative discourse in Austen's Emma: A Bakhtinian review. K@ta : a Biannual Publication on the Study of Language and Literature, 15(1), 1-8.

O'Brien, T. (1990). The things they carried. New York: Broadway.

Pennycook, A. (2010). Language as a local practice. New York: Routledge.

Popova, Y. B. (2014). Narrativity and enaction: The social nature of literary narrative understanding. Frontiers of Psychology, 5, 895, 1-14.

Popova, Y. B. (2015). Stories, meaning, and experience: Narrativity and enaction. New York: Routledge.

Raimondi, V. (2014). Social interaction, languaging and the operational conditions for the emergence of observing. Frontiers in Psychology, 5, 899. Retrieved from http://tinyw.in/kamd

Rosenblatt, L. (1978). The reader, the text, the poem. Portsmouth, NH: Boynton-Cook.

Roth, W-M. (2014). Curriculum*-in-the-making: A Post-constructivist perspective. New York: Peter Lang.

Sherry, M. B. (2014). Indirect challenges and provocative paraphrases: Using cultural conflict-talk practices to promote students' dialogic participation in whole-class discussions. Research in the Teaching of English, 49(2), 141-167.

Skaftun, A. (2011). Minding metaphors: Rethinking the ecology of written language. L1-Educational Studies in Language and Literature, 11, 39-50.

Shehadeh, A. (2011). Effects and student perceptions of collaborative writing in L2. Journal of Second Language Writing, 20, 286-305.

Tomasello, M. (2014). A natural history of human thinking. Cambridge, MA: Harvard University Press.

Welch, N. (1998). Sideshadowing teacher response. College English, 60(4), 374-395.

Wigglesworth, G., \& Storch, N. (2012). What role for collaboration in writing and writing feedback. Journal of Second Language Writing, 21, 364-374.

Yang, L. (2016). Languaging in story rewriting tasks by Chinese EFL students. Language Awareness, 25(3), 241-255.

Zunshine, L. (2006). Why we read fiction: Theory of mind and the novel. Columbus, OH: Ohio State University Press. 


\section{Acknowledgements}

I wish to thank Ms. Mary Bianchi, the teacher in this project, for generating these engaging rewriting activities; the four students for their creative work; and Ana Marjanovic-Shane and reviewers for their helpful suggestions for revisions.

\section{(c) EY EY}

New articles in this journal are licensed under a Creative Commons Attribution 4.0 United States License.

\section{ULLS}

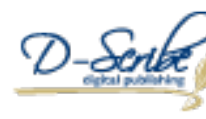

This journal is published by the University Library System, University of Pittsburgh as part of its D-Scribe Digital Publishing Program and is cosponsored by the University of Pittsburgh Press. 